\title{
Applying the sub-index model to evaluate the quality of water for irrigation purposes, a case study: wells water of left side from Mosul city, Iraq
}

\author{
Noor A.S. Al-Hamdany ${ }^{1}$, Abdalaziz Y.T. Al-Saffawi ${ }^{2 *}$, Yusra. M.S. Al-Shaker ${ }^{1}$ \\ ${ }^{1}$ Department of Environmental Science College of Environmental Science \& Technology University of Mosul. Iraq \\ ${ }^{2}$ Department of Biology College of Education For pure Sci. University of Mosul. Iraq \\ Corresponding Author: Email: alsaffawia2025@uomosul.edu.iq
}

Received 28 June 2020; Accepted 10 September 2020

\begin{abstract}
The present study aims to assess the quality of well water in some areas of the left side of Mosul city for irrigation; Water samples were collected from twelve wells scattered in the neighborhoods of Al-Muthana, Al-Zohoor, Al-Siddiq and AlHadba from November 2019 to January 2020 to measure the physical and chemical properties of wells and applying the subindicator model to evaluate the water quality. The results of the study indicated the suitability of well water quality for irrigation, where the WQI values ranged between (34.5-59.8), which indicates that the water quality from good water type to excellent quality for irrigation, and this relative deterioration is due to the high values of $\mathrm{pH}, \mathrm{EC}_{25}, \mathrm{P}$. Salinity, $\mathrm{Mg}$ Hazard and $\mathrm{HCO}_{3}$ ions as well as the effect of the relative weight (Wi) that was reflected in the values of (IWQI) and confirmed by the effective weight values (EWi) for each parameter that ranged between (15.0-22.8), (16.1-21.3), (27.5-34.5), (11.9-15.9) and (7.23-9.47), consecutive.
\end{abstract}

Keyword: Groundwater quality, IWQI, Irrigation water indexes

\section{INTRODUCTION}

The shortage of water resources with increasing demand for it leads to many critical problems for many countries of the world, as the water problem is one of the important pillars of national security, especially in the arid and semi-arid regions whose water sources are from the neighboring countries, as is the case in Iraq, Egypt, Sudan, etc., which adds threats to climate challenges and the scarcity of rains, and the water deficit problem may turn into an economic and political weapon, which increases the potential for tensions and wars with the continuing need for water, as is the case with the Alnatha Dam on the Nile river, which led to congestion of Egyptian and Sudanese positions towards Ethiopia as a result of the low water quotas for both countries.

Also, the future dimensions of the Iraqi country will be dire due to external challenges such as the construction of dams and irrigation projects in the upstream countries as well as traditional irrigation operations and waste in water consumption (Al-Saffawi, 2018a; Saleh et al., 2020), all of which led to the transformation of the water crisis into a problem Global due to social, economic, industrial developments and climate change (Ewaid et al., 2019), and that the requirements of population growth in these areas are met by preserving groundwater resources; As is the water quality of groundwater in such crucial areas characterized by semi-arid climate and affected water quality in general human and agricultural activities (Alwan et al., 2020; El Baba et al., 2020).

For Iraq, most of the groundwater suffers from the problem of salinity due to its exposure to the geological layers, especially the Al-Fatha formation and the geoche- mical reactions that occur in it in addition to the possibility of contamination with agricultural fertilizers and civil and industrial wastes that can leak into the ground water through the permeable layers, which limits uses of the water (Ehab et al., 2020) Therefore, these problems must be studied seriously to provide all the necessary means to confront these problems and reduce them in order to preserve agricultural lands, such as the use of modern irrigation techniques and determining the quality of water using modern methods of assessment such as the use of mathematical models (WQI) that depend on collecting information related to the specific characteristics of water in periods And different locations (Patil et al., 2020). In general, the quality of irrigation water depends on the following factors (Al-Saffawi, 2020a):

1. Salinity Hazards 


\section{Al-Hamdany et al. \\ Applying the sub-index model to evaluate the quality of water for irrigation purposes, a case study: wells water of left side from Mosul city, Iraq}

2. Permeability and filtering damage.

3. Ionic toxicity.

4. Various influences.

Salinity includes both the electrical conductivity and P. Salinity, as for the permeability and filtration damage, sodium ions are represented, such as the permeability index (PI), sodium percentage (\% Na), sodium adsorption retio (SAR), and the resudial sodium carbonate RSC (Al-Saffawi and Al-Sangari, 2018). As for the toxicity of sodium and chloride ions that leads to the deterioration of plant growth and production, which depends on the type of plant and the rate of water absorption and the toxicity problem is often associated with the problem of salinity and permeability (Mahanta et al., 2020).

Acid water caused inhibition of roots absorption of calcium and magnesium ions, while the basal water is suitable for the absorption of many plant nutrients, but it causes the problem of forming a solid layer of $\mathrm{CaCO}_{3}$ in the soil that impedes the spread of the roots (Ameloko and Ayolabi, 2018). Also, the high concentration of carbonate and bicarbonate ions is responsible for raising the value of the $\mathrm{pH}$ more than 8.3, thus working to deposit $\mathrm{Ca}$ and $\mathrm{Mg}$ ions leaving $\mathrm{Na}$ ions in the soil solution, which affects soil texture and plant growth (Chen et al., 2019).

Therefore, the water quality must be determined using the water quality models (WQI), which are good ways to give an image of the water quality for different uses. As these models give one value that reflects the different overlaps of the qualitative characteristics of water instead of the huge amount of data (Al-Saffawi, 2019), the use of these models has spread in Iraq recently, and there are many studies on the evaluation of surface and groundwater for different uses, including studies conducted in Nineveh governorate by: Al-Saffawi et al. (2018); Al-Saffawi \& Al-Sangary (2018); Al-Saffawi et al. (2020b); Talaat et al. (2019) and Al-Hamadany et al. (2020).

Therefore, this study came to evaluate the groundwater quality of the quarters of Al-Muthana, Al-Zohour, AlSiddiq and Al-Hadba for the irrigation of home gardens, trees and small agricultural fields spread in the area using the water quality index (IWQI).

\section{MATERIALS AND METHODS}

The current study included a number of quarters on the left side of the city of Mosul in northern Iraq and included four quarters (Muthanna, Al-Zuhur, Siddiq and Al-Hadba) with a high population density, and the study area is characterized by a hot dry climate in summer and cold rainy winter "so that the rate of rain precipitation reaches $279 \mathrm{~mm}$ for the other two decades according to the data of the meteorological station in Mosul city, the study area is about 250 meters above sea level, and as a result of the difficult conditions that Iraq has gone through, which led to the destruction of the infrastructure, including the transmission and distribution networks of electricity and drinking water, which prompted the residents to dig private wells, most of the wells studied are of a superficial type, with the exception of four wells in Al-Siddiq and Al-Hadba quarters that are of deep wells to exceed their depths of $20 \mathrm{~m}$ (Talat et al., 2019). The coordinates of the locations of the wells studied using the GPS of the Google Earth have been installed, as shown in (Fig. 1) and Table (1) that clarifies their characteristics and uses.

As for the geology of the study area, it is characterized by the presence of Formation Fatha, which was called (Formation Lower Faris) which dates back to the era of (Middle Miocene), and plays an important role in determining the quality of ground water passing through it and contains rocks that are very rich in evaporation salts with a high ability to dissolve in water, Gypsum $\left(\mathrm{CaSO}_{4} \cdot 2 \mathrm{H}_{2} \mathrm{O}\right)$ and Anhydrite $\left(\mathrm{CaSO}_{4}\right)$, which interfere with limestone, red marl.... etc. (Talat et al., 2019), and the Injana Formation, which dates back to (Upper Miocene Pliocene) and is characterized by its containment of river sediments and consists of the succession of layers of clay, alluvial and sandy sand. This formation covers a large part of the study area. (Al-Hamdany et al., 2020). A 168 water samples from twelve wells scattered in the study area were collected randomly from October 2019 to January 2020 using clean polyethylene bottles washed with the sample water several times before filling them, and kept inside a dark container until reaching the laboratory to perform the Chemical and physical tests according to international methods adopted (APHA., 1998, 2017). and the criteria for irrigation water were calculated like: sodium adsorption ratio (SAR), sodium percentage $(\% \mathrm{Na})$, residual sodium carbonate $(\mathrm{RSC})$, magnesium hazard $(\mathrm{MH})$, potential salinity (PS), kelly ratio(KR) and permeability index (PI) as from the following equations (AlSaffawi et al., 2019 ; Al-Saffawi et al., 2020): 


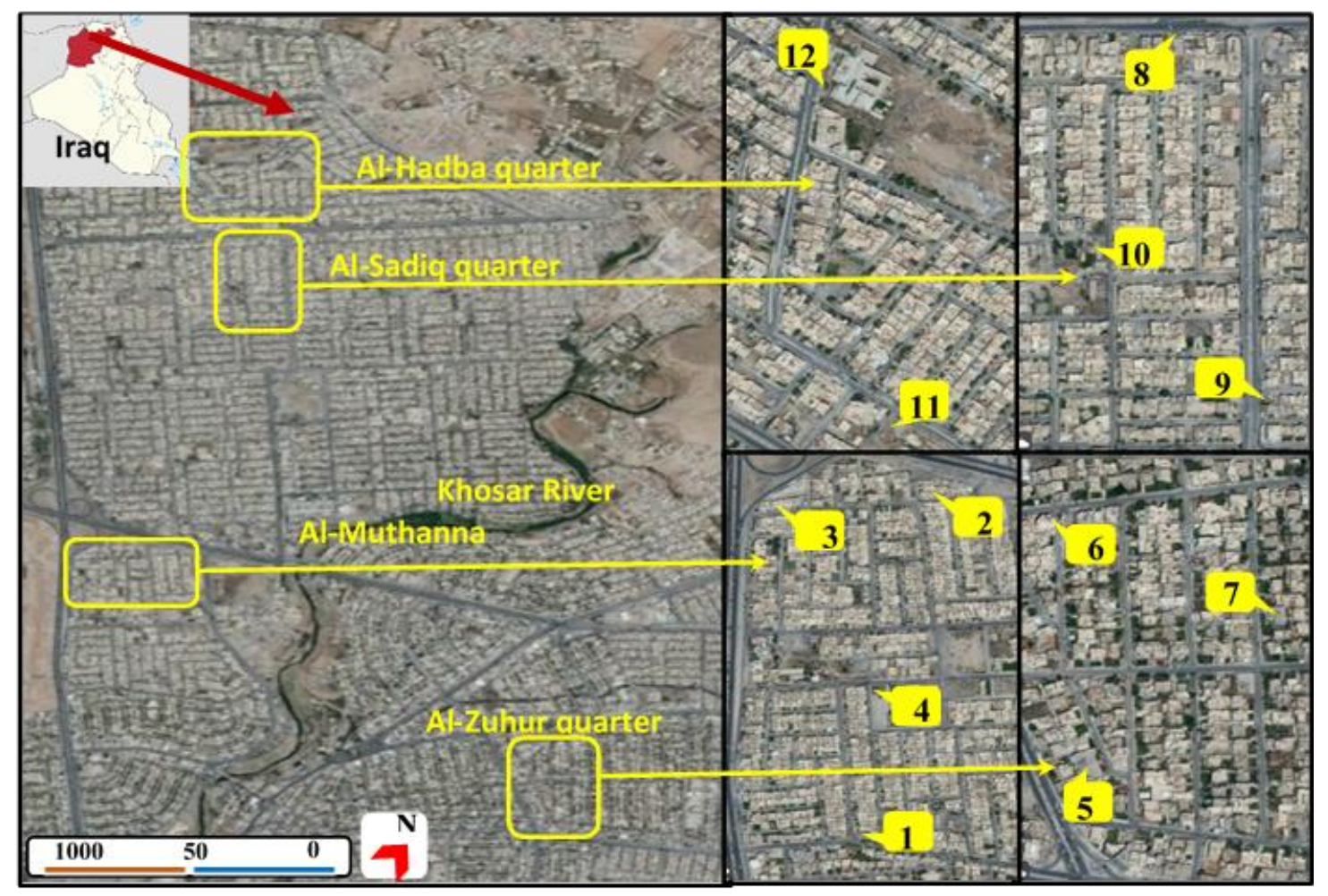

Figure 1: Well sites and quarters on the left side of the city of Mosul.

Table 1: Coordinates and specifications of water wells in the studied quarters on the left side of Mosul.

\begin{tabular}{lccccc}
\hline \multicolumn{1}{c}{ Well sites } & & $\mathbf{E}$ & $\mathbf{N}$ & Depth $(\boldsymbol{m})$ & Using \\
\hline Al-Mothana Qaurter & 1 & $43^{\circ} 16^{\prime} 73^{\prime \prime}$ & $36^{\circ} 37^{\prime} 63^{\prime \prime}$ & 12 & For different \\
& 2 & $43^{\circ} 16^{\prime} 50^{\prime \prime}$ & $36^{\circ} 37^{\prime} 92^{\prime \prime}$ & 10 & uses \\
& 3 & $43^{\circ} 16^{\prime} 31^{\prime \prime}$ & $36^{\circ} 37^{\prime} 74^{\prime \prime}$ & 10 & \\
& 4 & $43^{\circ} 16^{\prime} 65^{\prime \prime}$ & $36^{\circ} 37^{\prime} 66^{\prime \prime}$ & 10 & \\
\hline Al-Zohoor Qaurter & 5 & $43^{\circ} 18^{\prime} 84^{\prime \prime}$ & $36^{\circ} 37^{\prime} 98^{\prime \prime}$ & 7.0 & \\
& 6 & $43^{\circ} 18^{\prime} 52^{\prime \prime}$ & $36^{\circ} 38^{\prime} 16^{\prime \prime}$ & 50 & \\
\hline Al-Sideq Qaurter & 7 & $43^{\circ} 18^{\prime} 79^{\prime \prime}$ & $36^{\circ} 38^{\prime} 33^{\prime \prime}$ & 6.0 & \\
& 8 & $43^{\circ} 15^{\prime} 50^{\prime \prime}$ & $36^{\circ} 39^{\prime} 35^{\prime \prime}$ & 35 & \\
& 9 & $43^{\circ} 16^{\prime} 10^{\prime \prime}$ & $36^{\circ} 39^{\prime} 10^{\prime \prime}$ & 9.0 & \\
Al-Hadba Q. & 10 & $43^{\circ} 15^{\prime} 57^{\prime \prime}$ & $36^{\circ} 39^{\prime} 22^{\prime \prime}$ & 28 & \\
& 11 & $43^{\circ} 14^{\prime} 92^{\prime \prime}$ & $36^{\circ} 39^{\prime} 44^{\prime \prime}$ & 67 & \\
\hline
\end{tabular}

$\mathrm{SSP}=(\mathrm{Na}+\mathrm{K}) \times 100 /(\mathrm{Ca}+\mathrm{Mg}+\mathrm{Na}+\mathrm{K})$

$\mathrm{SAR}=[\mathrm{Na}] /\{(\mathrm{Ca}+\mathrm{Mg}) / 2\}^{1 / 2}$

$\left.\mathrm{PI}=\left[\mathrm{Na}+\left(\mathrm{HCO}^{3}\right)^{1 / 2}\right] \times 100 /(\mathrm{Ca}+\mathrm{Mg}+\mathrm{Na})\right]$

$\mathrm{RSC}=\left(\mathrm{CO}_{3}+\mathrm{HCO}_{3}\right)-(\mathrm{Ca}+\mathrm{Mg})$

$1 / 2 \mathrm{SO}_{4}+\mathrm{Cl}=\mathrm{PS}$

$\mathrm{KR}=\mathrm{Na} /(\mathrm{Ca}+\mathrm{Mg})$

Where units are used with the meq/ 1 .

\subsection{Calculating of the Water Quality Index (IWQI):}

The weighted mathematical model (IWQ1) referred to by the researchers (Agyemang, 2020; Alghamdi et al., 2020) was used and this model was applied using eleven criteria (as shown in Table 2) to assess water quality and the water quality index was calculated. (WQI) according to the following four equations:

$\mathrm{Wi}=\frac{w i}{\sum_{i=i}^{n} w i}$

$\mathrm{Qi}=\frac{C i}{S i} \times 100$

$\mathrm{SLi}=\mathrm{Wi} \times \mathrm{Qi}$

$\mathrm{IWQI}=\Sigma \mathrm{Sli}$ 
Al-Hamdany et al.

Applying the sub-index model to evaluate the quality of water for irrigation purposes, a case study: wells water of left side from Mosul city, Iraq

Where: Wi: Relative weight, w: weight value for each property, Si: standard concentration, Qi: quality rating of each parameter, Ci: measured value, Sli: sub-index., IWQI: Irrigation Water Quality Index.

Table 2: Standard limits (Si), weight (wi) and relative weight (Wi) for each parameter

\begin{tabular}{lccc}
\hline Parameters & Si & wi & Wi \\
\hline $\mathrm{PH}$ & $6.5-7.5$ & 4 & 0.093000 \\
\hline $\mathrm{EC}_{25}(\mu \mathrm{S} / \mathrm{cm})$ & 2000 & 5 & 0.116200 \\
\hline $\mathrm{Cl}(\mathrm{meq} / \mathrm{l})$ & 10 & 3 & 0.069700 \\
\hline $\mathrm{HCO}_{3}(\mathrm{meq} / \mathrm{l})$ & 8.5 & 3 & 0.069700 \\
\hline $\mathrm{RSC}(\mathrm{meq} / \mathrm{l})$ & 2.25 & 2 & 0.046500 \\
\hline $\mathrm{PI}$ & 75 & 5 & 0.116200 \\
$\mathrm{Na}(\%)$ & 60 & 4 & 0.093000 \\
\hline $\mathrm{SAR}$ & 18 & 5 & 0.116200 \\
\hline $\mathrm{MAR}$ & 50 & 4 & 0.093000 \\
\hline $\mathrm{PS}(\mathrm{meq} / \mathrm{l})$ & 7 & 5 & 0.116200 \\
\hline $\mathrm{KI}$ & 1 & 3 & 0.069700 \\
\hline $\mathbf{2}$ & & 43 & 1.000000 \\
\hline
\end{tabular}

In order to judge and make sure of the effect of each parameter on the IWQI value, the effective weight (Ewi) for each parameter is calculated by dividing the sub-index (Sli) for each studied parameter by the value of (IWQI) multiplied by 100, and whenever the value of (Ewi) is large, this means its significant effect on the rise in the value of (IWQI) and the deterioration of water quality, as shown in the following equation (Ibrahim, 2019):

$\mathrm{E}_{\mathrm{Wi}}=\frac{S l i}{I W Q I} \times 100$

After finding IWQI values, they are classified into five categories: Excellent Quality water (IWQI 55 >), good (IWQI 50-100), poor (IWQI 100-200), very poor (IWQI 200-300) and inadequate quality (IWQI >300) (Maskooni et al, 2020).

\section{RESULTS AND DISCUSSION}

Sub-index Model was applied to eleven criteria for evaluating the studied wells water for irrigation, such as ( $\mathrm{pH}$ and electrical conductivity $\mathrm{EC}_{25}$, chlorides $(\mathrm{Cl})$ and bicarbonate $\left(\mathrm{HCO}_{3}\right)$ ions, residual sodium carbonate (RSC), and permeability index (PI), sodium percentage $\% \mathrm{Na}$, sodium adsorption retio (SAR), magnesium hazard (M. H) potantional salinity (P.S) and Kelly index (PI) and comparing it with the global standard irrigation limits mentioned by (Moghimi, 2016).

The results shown in Table (3) indicate that the IWQI values ranged between (35.9 to 61.1) and when compared it whith water quality classification, it was found that $67 \%$ of the studied water samples were of good water quality class except for wells 4, 5, 8 and 9 were excellent water quality, this is due to the concentrations of most studied criteria not exceeding the permissible upper limits for irrigation water. It is noted from Table (3) that the sub-index (Sli) values used to calculate the water quality index (IWQI) were relatively high for most wells and for some characteristics studied, especially the values of $\mathrm{pH}$, electrical conductivity $\left(\mathrm{EC}_{25}\right)$, potantional salinity (PS), magnesium hazard (MH) and bicarbonate ion $\left(\mathrm{HCO}_{3}\right)$.

As well as the effect of the relative weight (Wi) that was reflected on the values of (IWQI), and this is confirmed by the values of the effective weight (EWi) for each parametr that ranged between (15.0 to 22.8), (16.1 to 21.3), (27.5 to 34.5), (11.9 to15.9) and (7.23 to 9.47) consecutive, as shown in Table (4), while the values of the sub-index (Sli) were relatively low for wells 4, 5, 8, and 9 for values of $\mathrm{EC}_{25}, \mathrm{HCO}_{3}$, and PS, which reflected positively on the values of the (IWQI) and made it an excellent water class. This is confirmed by the effective weight values for each criterion (EWi), as the values ranged from (6.89 to 15.6), (6.79 to 9.65) and (11.1 to 22.9) consecutive. 
Table 3: The quality rating (Qi) and sub-index values (Sli) for each parameter

\begin{tabular}{|c|c|c|c|c|c|c|c|c|c|c|c|c|c|}
\hline \multirow{2}{*}{\multicolumn{2}{|c|}{$\begin{array}{c}\text { Wells } \\
\text { Parameters }\end{array}$}} & \multicolumn{4}{|c|}{ Al-Mothana Qaurter } & \multicolumn{3}{|c|}{ Al-Zohoor Q. } & \multicolumn{3}{|c|}{ Al-Sideq Qaurt. } & \multicolumn{2}{|c|}{ Al.Hadba Q. } \\
\hline & & \multirow{2}{*}{$\begin{array}{c}1 \\
95.3\end{array}$} & \multirow{2}{*}{$\begin{array}{c}2 \\
95.6\end{array}$} & \multirow{2}{*}{$\begin{array}{c}3 \\
95.3\end{array}$} & \multirow{2}{*}{$\begin{array}{c}4 \\
97.8\end{array}$} & \multirow{2}{*}{$\begin{array}{c}5 \\
99.4\end{array}$} & \multirow{2}{*}{$\begin{array}{c}6 \\
101\end{array}$} & \multirow{2}{*}{$\begin{array}{c}7 \\
97.6\end{array}$} & \multirow{2}{*}{$\begin{array}{c}8 \\
98.1\end{array}$} & \multirow{2}{*}{$\begin{array}{c}9 \\
97.7\end{array}$} & \multirow{2}{*}{$\begin{array}{c}10 \\
97.6\end{array}$} & \multirow{2}{*}{$\begin{array}{c}11 \\
97.6\end{array}$} & \multirow{2}{*}{$\begin{array}{c}12 \\
99.7\end{array}$} \\
\hline $\mathrm{PH}$ & Qi & & & & & & & & & & & & \\
\hline & Sli & 8.87 & 8.89 & 8.87 & 9.10 & 9.25 & 9.37 & 9.08 & 9.13 & 9.09 & 9.08 & 9.08 & 9.27 \\
\hline \multirow[t]{2}{*}{$\mathrm{EC}_{25}$} & Qi & 81.6 & 74.4 & 91.2 & 23.6 & 43.2 & 87.1 & 98.4 & 64.0 & 54.4 & 80.7 & 85.2 & 77.4 \\
\hline & Sli & 9.48 & 8.65 & 10.6 & 2.75 & 5.02 & 10.1 & 11.4 & 7.44 & 6.32 & 9.38 & 9.91 & 9.00 \\
\hline \multirow[t]{2}{*}{$\mathrm{Cl}$} & Qi & 18.2 & 21.5 & 27.5 & 10.0 & 16.1 & 31.2 & 30.4 & 21.0 & 17.8 & 24.3 & 27.9 & 22.0 \\
\hline & Sli & 1.27 & 1.40 & 1.92 & 0.70 & 1.12 & 2.17 & 2.12 & 1.46 & 1.24 & 1.69 & 1.94 & 1.53 \\
\hline \multirow[t]{2}{*}{$\mathrm{HCO}_{3}$} & Qi & 74.4 & 69.5 & 79.1 & 38.8 & 52.8 & 55.6 & 63.4 & 66.0 & 62.2 & 69.8 & 69.4 & 70.3 \\
\hline & Sli & 5.19 & 4.85 & 5.52 & 2.71 & 3.68 & 3.88 & 4.42 & 4.60 & 4.34 & 4.87 & 4.84 & 4.90 \\
\hline \multirow[t]{2}{*}{ RSC } & Qi & 0.00 & 0.00 & 0.00 & 0.00 & 0.00 & 0.00 & 0.00 & 0.00 & 0.00 & 0.00 & 0.00 & 0.00 \\
\hline & Sli & 0.00 & 0.00 & 0.00 & 0.00 & 0.00 & 0.00 & 0.00 & 0.00 & 0.00 & 0.00 & 0.00 & 0.00 \\
\hline \multirow[t]{2}{*}{ PI } & Qi & 23.1 & 29.8 & 24.5 & 46.0 & 44.3 & 36.5 & 26.5 & 35.9 & 41.7 & 28.0 & 27.8 & 26.9 \\
\hline & Sli & 2.68 & 3.46 & 2.85 & 5.34 & 5.15 & 4.24 & 3.08 & 4.17 & 4.85 & 3.25 & 3.23 & 3.13 \\
\hline \multirow[t]{2}{*}{$\% \mathrm{Na}$} & Qi & 11.3 & 15.7 & 13.8 & 16.0 & 22.1 & 24.7 & 18.0 & 20.8 & 21.0 & 17.5 & 19.3 & 14.0 \\
\hline & Sli & 1.05 & 1.46 & 1.29 & 1.49 & 2.01 & 2.30 & 1.68 & 1.94 & 1.87 & 1.63 & 1.80 & 1.63 \\
\hline \multirow[t]{2}{*}{ SAR } & Qi & 2.17 & 2.72 & 2.72 & 1.78 & 3.33 & 4.33 & 3.56 & 3.39 & 3.00 & 3.44 & 3.17 & 2.44 \\
\hline & Sli & 0.25 & 0.32 & 0.32 & 0.21 & 0.39 & 0.50 & 0.41 & 0.32 & 0.35 & 0.40 & 0.37 & 0.28 \\
\hline \multirow[t]{2}{*}{ M.H } & Qi & 93.7 & 85.0 & 80.2 & 90.2 & 78.4 & 80.0 & 75.4 & 76.0 & 89.0 & 86.5 & 44.1 & 67.8 \\
\hline & Sli & 8.72 & 7.91 & 7.46 & 8.40 & 7.29 & 7.52 & 7.01 & 7.07 & 8.28 & 8.05 & 7.17 & 6.31 \\
\hline \multirow[t]{2}{*}{ P.S } & Qi & 143 & 123 & 169 & 38.1 & 56.2 & 138 & 182 & 93.8 & 67.8 & 141 & 156 & 137 \\
\hline & Sli & 16.5 & 14.3 & 19.6 & 4.43 & 6.54 & 16.0 & 21.1 & 10.9 & 7.89 & 16.3 & 18.1 & 15.8 \\
\hline \multirow[t]{2}{*}{ KI } & Qi & 7.00 & 10.0 & 9.0 & 11.0 & 18.0 & 18.0 & 11.0 & 15.0 & 14.0 & 12.0 & 11.0 & 9.00 \\
\hline & Sli & 0.49 & 0.70 & 0.63 & 0.77 & 1.25 & 1.25 & 0.77 & 1.05 & 0.98 & 0.84 & 0.77 & 0.63 \\
\hline \multirow[t]{2}{*}{ WQI } & Value & 54.5 & 51.9 & 59.1 & 35.9 & 41.7 & 57.3 & 61.1 & 48.1 & 45.2 & 55.5 & 57.2 & 52.48 \\
\hline & Status & G. & G. & G. & Exc. & Exc. & G. & G. & Exc. & Exc. & G. & G. & G. \\
\hline
\end{tabular}

G: Good quality, Exc: Excellent qaulity

This is confirmed by the results of the qualitative characteristics shown in Table (5), as for the damages of salinity represented by electrical conductivity and P. S, there is no problem despite the relatively high values of electrical conductivity, where their averges fluctuated between (864 to 1968) $) \mu \mathrm{S} / \mathrm{cm}$ However, they did not exceed the permissible limits for irrigation (Moghimi, 2016) and these differences may be due to the presence of Al-Fatha formation containing the evaporated salts, gypsum, dolomite, and the formation of Anjana, and this will be reflected in the quality of the water passing through it(Talat et al, 2019). ). Also, the values of potential salinity in well water, it ranged between 1.66 to $21.4 \mathrm{meq} / 1$. Thus, \% 64 of the water samples were of medium quality for highly permeable soils, while the percentage drops to \% 20 when using water to irrigate heavy soils (Clay soils) according to Doneen classification (Al-Asaaf et al, 2020). As for the Hazard of Infiltration and Permeability for soils irrigated with this water, there is no problem because the values of both SAR and RSC were within the permissible upper limits as is the case with the values of the PI, as it was good quality for $64 \%$ of the studied samples (Moghimi, 2016), as shown in the table (5). Likewise with regard to the toxicity of both chloride ions and the properties of irrigation water related to sodium there is no problem despite the relatively high chloride ions due to the natural geological formations that water passes through and the effect of wastewater (Danhalihu et al., 2018). 
Al-Hamdany et al.

Applying the sub-index model to evaluate the quality of water for irrigation purposes, a case study: wells water of left side from Mosul city, Iraq

Table 4: Effective weight values (EWi) for each parameter of studied wells water

\begin{tabular}{|c|c|c|c|c|c|c|c|c|c|c|c|c|}
\hline \multirow{2}{*}{$\begin{array}{l}\text { Wells } \\
\text { Param. }\end{array}$} & \multicolumn{4}{|c|}{ Al-Mothana Qaurter } & \multicolumn{3}{|c|}{ Al-Zohoor Q. } & \multicolumn{3}{|c|}{ Al-Sideq Qaurt. } & \multicolumn{2}{|c|}{ Al.Hadba Q. } \\
\hline & 1 & 2 & 3 & 4 & 5 & 6 & 7 & 8 & 9 & 10 & 11 & 12 \\
\hline $\mathrm{PH}$ & 16.2 & 17.1 & 15.0 & 22.8 & 20.6 & 19.8 & 14.9 & 19.2 & 20.1 & 16.2 & 15.8 & 17.5 \\
\hline $\mathrm{EC}_{25}$ & 17.3 & 16.6 & 17.9 & 6.89 & 11.2 & 21.3 & 18.7 & 15.6 & 13.1 & 16.7 & 17.3 & 16.1 \\
\hline $\mathrm{Cl}$ & 2.32 & 2.70 & 3.25 & 1.75 & 2.49 & 4.58 & 3.47 & 3.06 & 2.74 & 3.02 & 3.39 & 2.89 \\
\hline $\mathrm{HCO}_{3}$ & 9.47 & 9.34 & 9.33 & 6.79 & 8.18 & 8.17 & 7.23 & 9.65 & 9.60 & 8.69 & 8.45 & 9.24 \\
\hline PI & 4.89 & 6.66 & 4.82 & 13.4 & 11.4 & 8.94 & 5.04 & 8.74 & 10.7 & 5.80 & 5.64 & 5.90 \\
\hline$\% \mathrm{Na}$ & 1.20 & 2.81 & 2.18 & 3.73 & 4.47 & 4.85 & 2.75 & 4.07 & 4.14 & 2.91 & 3.14 & 3.07 \\
\hline SAR & 0.45 & 0.62 & 0.54 & 0.52 & 0.87 & 1.05 & 0.67 & 0.67 & 0.77 & 0.71 & 0.65 & 0.53 \\
\hline $\mathrm{MH}$ & 15.9 & 15.2 & 12.6 & 21.1 & 16.2 & 15.8 & 11.5 & 14.8 & 18.3 & 14.4 & 12.5 & 11.9 \\
\hline P.S & 30.1 & 27.5 & 33.2 & 11.1 & 14.5 & 33.7 & 34.5 & 22.9 & 17.5 & 29.1 & 31.6 & 29.8 \\
\hline KI & 0.89 & 1.35 & 1.07 & 1.93 & 2.77 & 2.64 & 1.26 & 2.20 & 2.17 & 1.50 & 1.34 & 1.19 \\
\hline
\end{tabular}

Table 5: Results of analyzing well water in some quarters on the left side of Mosul

\begin{tabular}{|c|c|c|c|c|c|c|c|c|c|c|c|c|c|}
\hline \multirow{2}{*}{\multicolumn{2}{|c|}{$\begin{array}{l}\text { Wells } \\
\text { Param. }\end{array}$}} & \multicolumn{4}{|c|}{ Al-Mothana Qaurter } & \multicolumn{3}{|c|}{ Al-Zohoor Q. } & \multicolumn{3}{|c|}{ Al-Sideq Qaurt. } & \multicolumn{2}{|c|}{ Al.Hadba Q. } \\
\hline & & 1 & 2 & 3 & 4 & 5 & 6 & 7 & 8 & 9 & 10 & 11 & 12 \\
\hline \multirow[t]{3}{*}{ PH } & Min & 6.17 & 6.82 & 6.81 & 7.06 & 7.05 & 7.07 & 6.79 & 7.07 & 7.08 & 6.09 & 7.11 & 6.99 \\
\hline & $\operatorname{Max}$ & 7.49 & 7.41 & 7.35 & 7.72 & 7.78 & 7.80 & 7.61 & 7.59 & 7.54 & 7.81 & 7.51 & 9.67 \\
\hline & Mean & 7.15 & 7.17 & 7.15 & 7.34 & 7.46 & 7.55 & 7.32 & 7.36 & 7.33 & 7.32 & 7.32 & 7.48 \\
\hline $\mathrm{EC}_{25}$ & Min & 1587 & 1434 & 1750 & 353 & 835 & 1391 & 1865 & 1264 & 1016 & 1058 & 1242 & 1119 \\
\hline \multirow[t]{2}{*}{$\mu S / \mathrm{cm}$} & $\operatorname{Max}$ & 1693 & 1552 & 1924 & 1230 & 906 & 2073 & 2145 & 1312 & 1554 & 1737 & 2126 & 2366 \\
\hline & Mean & 1632 & 1488 & 1825 & 473 & 864 & 1741 & 1968 & 1281 & 1088 & 1614 & 1705 & 1549 \\
\hline Cl & Min & 46.0 & 54.0 & 58.0 & 24.0 & 32.0 & 58.0 & 84.0 & 45.0 & 30.0 & 75.0 & 70.0 & 52.0 \\
\hline \multirow[t]{2}{*}{ meq/l } & $\operatorname{Max}$ & 180 & 100 & 184 & 85 & 115 & 265 & 141 & 150 & 120 & 113 & 140 & 200 \\
\hline & Mean & 65.8 & 76.2 & 95.9 & 38.1 & 56.6 & 130 & 108 & 77.1 & 62.6 & 86.2 & 99.5 & 82.3 \\
\hline $\mathrm{HCO}_{3}$ & Min & 3.80 & 4.00 & 4.39 & 2.20 & 2.44 & 3.28 & 3.92 & 3.67 & 3.39 & 4.30 & 4.66 & 4.08 \\
\hline \multirow[t]{2}{*}{ meq/l } & $\operatorname{Max}$ & 8.80 & 7.80 & 8.00 & 5.20 & 7.39 & 5.80 & 6.80 & 7.44 & 7.08 & 7.08 & 7.39 & 6.97 \\
\hline & Mean & 6.33 & 5.91 & 6.33 & 3.30 & 4.49 & 4.73 & 5.39 & 5.61 & 5.29 & 5.94 & 5.90 & 5.98 \\
\hline \multirow[t]{3}{*}{ PI } & Min & 11.3 & 17.3 & 13.8 & 21.5 & 21.2 & 17.7 & 14.6 & 19.7 & 24.1 & 17.7 & 16.3 & 14.1 \\
\hline & $\operatorname{Max}$ & 20.7 & 33.3 & 24.1 & 49.1 & 54.5 & 43.8 & 29.1 & 36.0 & 45.3 & 23.3 & 27.1 & 31.1 \\
\hline & Mean & 17.4 & 22.4 & 18.4 & 34.5 & 33.3 & 27.3 & 19.9 & 26.9 & 31.3 & 21.0 & 20.9 & 20.2 \\
\hline \multirow[t]{3}{*}{$\% \mathrm{Na}$} & Min & 3.83 & 6.01 & 4.93 & 6.00 & 7.54 & 6.77 & 6.66 & 5.85 & 7.95 & 8.47 & 6.62 & 5.88 \\
\hline & $\operatorname{Max}$ & 11.1 & 13.3 & 10.1 & 17.2 & 22.9 & 25.1 & 15.3 & 22.5 & 19.5 & 12.7 & 33.4 & 13.5 \\
\hline & Mean & 6.79 & 9.42 & 8.33 & 9.60 & 13.3 & 14.9 & 10.8 & 12.5 & 12.7 & 10.5 & 11.6 & 8.41 \\
\hline \multirow[t]{3}{*}{ SAR } & Min & 0.22 & 0.31 & 0.29 & 0.20 & 0.26 & 0.35 & 0.42 & 0.26 & 0.33 & 0.41 & 0.31 & 0.29 \\
\hline & $\operatorname{Max}$ & 0.75 & 0.63 & 0.69 & 0.62 & 1.06 & 1.17 & 0.81 & 1.25 & 0.94 & 0.80 & 0.89 & 0.64 \\
\hline & Mean & 0.39 & 0.49 & 0.49 & 0.32 & 0.60 & 0.78 & 0.64 & 0.61 & 0.54 & 0.62 & 0.57 & 0.44 \\
\hline \multirow[t]{3}{*}{ М.H } & Min & 44.0 & 32.0 & 32.0 & 38.0 & 25.0 & 36.0 & 28.0 & 22.0 & 35.0 & 35.0 & 31.0 & 25.0 \\
\hline & Max & 49.0 & 52.0 & 45.0 & 49.0 & 48.0 & 48.0 & 47.0 & 45.0 & 48.0 & 47.0 & 48.0 & 46.0 \\
\hline & Mean & 46.9 & 42.5 & 41.0 & 45.1 & 39.2 & 40.4 & 37.7 & 38.0 & 44.5 & 43.3 & 38.6 & 33.9 \\
\hline P.S & Min & 7.51 & 5.90 & 8.26 & 1.66 & 2.47 & 4.97 & 8.52 & 4.90 & 3.39 & 6.72 & 5.87 & 5.09 \\
\hline \multirow[t]{2}{*}{ meq/l } & $\operatorname{Max}$ & 14.3 & 11.3 & 16.9 & 5.76 & 6.78 & 15.6 & 16.6 & 8.61 & 5.93 & 11.8 & 21.4 & 20.4 \\
\hline & Mean & 9.98 & 8.61 & 11.8 & 2.67 & 3.94 & 9.64 & 12.7 & 6.57 & 4.75 & 9.84 & 10.1 & 9.57 \\
\hline \multirow[t]{3}{*}{ KI } & Min & 0.04 & 0.06 & 0.05 & 0.06 & 0.08 & 0.07 & 0.01 & 0.06 & 0.08 & 0.09 & 0.07 & 0.06 \\
\hline & $\operatorname{Max}$ & 0.13 & 0.15 & 0.12 & 0.21 & 0.30 & 0.34 & 0.18 & 0.29 & 0.24 & 0.15 & 0.19 & 0.16 \\
\hline & Mean & 0.07 & 0.10 & 0.09 & 0.11 & 0.18 & 0.18 & 0.11 & 0.15 & 0.14 & 0.12 & 0.11 & 0.09 \\
\hline
\end{tabular}

As for the effects Miscellaneous, there is no problem with the values of $\mathrm{pH}$ because the average $\mathrm{pH}$ value ranges between 7.15 to 7.55 , and therefore are within the permissible limits for irrigation. As is well known, acidic water impedes the absorption of calcium and magnesium ions through the roots, while alkaline water provides an appropriate environment for the absorption of many nutrients by the roots, but it is responsible for the accumulation of calcium carbonate and the formation of a solid layer that prevented the penetration of plant roots as well as high water due to Capillary characteristic, causing physiological drought (Saffawi et al. 2019a; Al-Saffawi, 2020). While 
there is a relative rise in the concentration of bicarbonate ions, where their rates ranged between 3.30 to $6.33 \mathrm{meq} / \mathrm{l}$, and so the water studied is classified from category of increasing problem (IP) according to Ayers \& Branson classification (Moghimi, 2016).

\section{CONCLUSIONS \& RECOMMENDATIONS}

Most of the studied water was characterized by the relatively high values of electrical conductivity, chloride ions and latent salinity, but most of the studied properties did not exceed the permissible limits for irrigation except for bicarbonate ions. Which was of the problem increase category, and when calculating the interventions for these characteristics using the water quality index, $67 \%$ of the water samples studied were of good water quality and the rest were excellent in irrigation.

Therefore, we recommend periodic checks of groundwater to stand in any emergency, with the use of mathematical models to evaluate water for different uses.

Acknowledgment: We thank the University of Mosul and the college of education for pure sciences for their support of all requirements of chemicals and media for bacterial testing and testing equipment during this study. The authors state that there is no conflict of interest.

Conflict of Interest: Authors declare that there is no conflict of interest.

\section{REFERENCES}

Agyemang, V.O. (2020). Hydro chemical Characterization and Assessment of Groundwater Suitability for Drinking, Domestic and Irrigation Purposes in the Agona East District, Ghana. Iconic Research and Engineering Journals (IREJ), 3(7), 112-125. ISSN: 2456-8880.

Al-Asaaf, A.Y.R., Talat, R.A., Al-Saffawi, A.Y.T. (2020). Suitability of water for irrigation purpose using IWQI model: The case study groundwater quality of some quarters in Mosul city,Iraq. Plant Archives. 20(Supplement 1): 1797-1802.

Alghamdi, A.G., Aly, A.A., Aldhumri, S.A., Al-Barakaha, F.N. (2020). Hydrochemical and Quality Assessment of Groundwater Resources in Al-Madinah City, Saudi Arabia. Sustainability, 12(8): 1-14. https://doi.org/10.3390/su12083106

Al-Hamdany, N.A.S., Al-Shaker, Y.M.S., Al-Saffawi, A.Y.T. (2020). Water quality assessment using the NSFWQI model for drinking and domestic purposes: A case study of groundwater on the left side of Mosul city. Iraq. Plant Archives. 20(1): 3079-3085

Al-Saffawi, A.Y.T. (2019). Water qualityindex assessment of ground water in Al- Nimrud district of Southeastern Mosul City. Iraq. Pakistan J. of Analytical Chemi. \& Envi. Sci., 20(1), 75-81. doi.org/10.21743/pjaec/2019.06.10

Al-Saffawi, A.Y.T., Al sinjari, W.E., AL-Taee Y.A.J. (2018) Assessment of groundwater quality using WQI in Gleewkhan village northeastern of Iraq. Int. J. of Enhanced Res. in Sci., Tech. and Eng., 7(5), 1-7. https://www.researchgate.net/publication/327832091

Al-Saffawi, A.Y.T., Al-Sanjari, W.E.A. (2018). Self-purification of waste water from the Kharazi valley. J. of Educ and Sci. 27 (4): 84-98. (In arabic).

Al-Saffawi, A.Y.T., Al-Asaaf, A.Y.R., Talat, R.A. (2020b). Valuation of water quality for livestock and poultry watering: a case study of groundwater in some areas of Mosul city, Iraq. Nipp. J. Env. Sci., 1(2): 1-7. https://doi.org/10.46266/njes.1006

Al-Saffawi, A.Y.T., Ibn Aubbakar, B.S.V., Abbass, L.Y., Monguno, A. K. (2020a). Assessment of ground water quality for potential irrigation purpose using the IWQI index in AL-Kasik substic.Iraq. Nigerian Journal of Technology (NIJOTECH). 39 (2), 632-638. http://dx.doi.org/10.4314/njt.v39i1.35

Alwan, A.S., Fayyadh, S.K., Ismaiel, M.H. (2020, March). Experimental and Numerical Analysis of Laser Surface Melting by Using Enthalpy Method. In The Fourth Postgraduate Engineering Conference, IOP Conf. Series: Materials Sci. and Engin. 745(012060), 1-12. https://doi:10.1088/1757-899X/745/1/012060

Ameloko, A., Ayolabi, E. A., Enaworu, E., and Bolujo, E. O. (2018). Assessment of leachate contamination of groundwater around Ighenre Ekotedo dumpste, OTA, Southwest Nigeria. Petroleum and Coal. 60(5): 890902.

APHA, AWWA, WCPE (1998). Stand Method for Examination of water and wastewater American public Health Association, $20^{\text {th }}$ ed., Washington DC, USA. 
APHA, AWWA, WCPE (2017). Stand Method for Examination of water and wastewater American public Health Association, $23^{\mathrm{RD}}$ ed., Washington DC, USA.

Chen, J., Huang, Q., Lin, Y., Fang, Y., Qian, H., Liu, R., Ma, H. (2019). Hydrogeochemical characteristics and quality assessment of groundwater in an irrigated region, China. Water. 11(1), 1-18. https://doi.org/10.3390/w11010096

Danhalihu, R.L., Mustapha, S.M., Aliyu, A.I. (2018). Groundwater quality in basement formation of Musawa LGA of katsina Dtate, northwestern Nigeria. Int. J. of Advanced Academic Res. Sci., Technology \& Engin., 4(4), 95-105.

Ehab Mohammad, A., Ektifa Taha, A., Fatma Adnan, S., Rania Haithem, S. (2020). Study of qualitative properties of groundwater and its suitability for different uses in the Eastern of the Al-Dour city/Salahaldin/Iraq. Tikrit J. of Pure Sci. 25(2), 47-53. http://dx.doi.org/10.25130/j.v25i2.957

El Baba, M., Kayastha, P., Huysmans, M., De Smedt, F. (2020). Evaluation of the Groundwater Quality Using the Water Quality Index and Geostatistical Analysis in the Dier al-Balah Governorate, Gaza Strip, Palestine. Water, 12(1), 1-14. https://doi.org/10.3390/w12010262

Ibrahim, M.N. (2019). Assessing Groundwater Quality for Drinking Purpose in Jordan: Application of Water Quality Index. Journal of Ecological Engineering, 20(3), 101-111. https://doi.org/10.12911/22998993/99740

Ismail, A. H., Hassan, G., \& Sarhan, A. H. (2020). Hydrochemistry of shallow groundwater and its assessment for drinking and irrigation purposes in Tarmiah district, Baghdad governorate, Iraq. Groundwater for Sustainable Develo., 10:1-12.

Jaafer, J.A., Al-Saffawi, A.Y.T. (2020). Application the logarithmic water quality index (WQI) to evaluate the wells water in Al-Rashidiya area, north Mosul, for drinking and civilian uses. Accepted for publication in PlantArchives, Vol. 20 No. 1 spesial issue, 2020.

Mahanta, N., Mishra, I., Hatui, A., Mahanta, P.S., Sahoo, H.K., Goswami, S. (2020). Geochemical appraisal of groundwater qualities and its uses in and around Maneswar Block of Sambalpur District, Odisha, India. Environmental Earth Sciences, 79(1), 1-13. https://doi.org/10.1007/s12665-019-8719-9

Maskooni, E.K., Berndtsson, R., Nakagawa, K. (2020). Use of Heavy Metal Content and Modified Water Quality Index to Assess Groundwater Quality in a Semiarid Area. Water, 12(4), 1115. https://doi.org/10.3390/w12041115

Moghimi, H. (2016). The Assessment of groundwater resources for irrigation by water quality index, case study Ghazvin plain, northwest Iran. Caspian Sea J. 10(4), 538-548.

Patil, V.B.B., Pinto, S.M., Govindaraju, T., Hebbalu, V.S., Bhat, V., Kannanur, L.N. (2020). Multivariate statistics and water quality index (WQI) approach for geochemical assessment of groundwater quality - a case study of Kanavi Halla Sub-Basin, Belagavi, India. Envi.l Geochem and Health, 1-18.

Talat, R.A., Al-Assaf, A.Y.R., Al-Saffawi, A.Y.T. (2019). Valuation of water quality for drinking and domestic purposes using WQI: Acase study for groundwater of Al-Gameaa and Al-Zeraee qaurters in Mosul city/Iraq. J. of Physics: Conference Series, 1294(7), 1-11. https:// doi:10.1088/1742-6596/1294/7/072011 